Penelitian

\title{
Identifikasi Penambahan Daging Babi pada Pangan Berbahan Dasar Daging Sapi Menggunakan ELISA dan qPCR
}

\author{
(Identification of Pork and Wild Boar Meat Alduteration in Beef \\ and Beef Product Using ELISA and qPCR) \\ Diyan Cahyaningsari', Hadri Latif ${ }^{2}$, Etih Sudarnika ${ }^{3}$ \\ 'Balai Pengujian Mutu dan Sertifikasi Produk Hewan Bogor \\ ${ }^{2}$ Divisi Kesehatan Masyarakat Veteriner, Fakultas Kedokteran Hewan Institut Pertanian Bogor \\ ${ }^{3}$ Divisi Epidemiologi, Fakultas Kedokteran Hewan Institut Pertanian Bogor \\ *Penulis untuk korespondensi: nazdcs@gmail.com \\ Diterima 6 September 2018, Disetujui 19 Maret 2019
}

\begin{abstract}
ABSTRAK
Penelitian ini bertujuan untuk mengidentifikasi dan menganalisis penambahan daging babi ternak dan babi hutan baik yang mentah (raw) maupun yang diolah (cooked) di dalam pangan asal hewan berbahan dasar daging sapi menggunakan metode uji enzyme-linked immunosorbent assay (ELISA) dan real-time PCR (qPCR). Sebanyak 40 sampel yang terdiri dari 20 daging babi ternak dan 20 daging babi hutan dihomogenisasi dengan daging sapi dalam bentuk mentah maupun olahan (bakso). Konsentrasi setiap daging babi ternak dan babi hutan dalam bentuk mentah dan olahan bakso pada campuran daging sapi adalah $2 \%, 1 \%, 0.5 \%, 0.25 \%$, dan $0.125 \%$. Pengujian ELISA menggunakan kit komersial dengan metode sandwich ELISA, sedangkan uji qPCR menggunakan kit komersial berdasarkan probe dimana primer dan probe sudah termasuk di dalam master mix kit komersial qPCR. Hasil uji ELISA pada penelitian ini menunjukkan bahwa uji ini mampu mengidentifikasi adanya penambahan daging babi ternak dan babi hutan dalam pangan asal hewan baik dalam bentuk mentah maupun olahan bakso hingga konsentrasi $0.25 \%$. Hasil uji t terhadap nilai optical density (OD) uji ELISA menunjukkan bahwa tidak terdapat perbedaan dalam mendeteksi spesies babi ternak dengan babi hutan ( $p \geq 0.05)$, tetapi terdapat perbedaan pada sampel bentuk mentah dengan bakso $(p<0.05)$. Hasil uji qPCR mampu mengidentifikasi adanya penambahan daging babi ternak dan babi hutan dalam pangan asal hewan baik dalam bentuk mentah maupun olahan bakso hingga konsentrasi $0.125 \%$. Hasil uji t terhadap nilai cycle threshold $(\mathrm{Ct})$ uji qPCR menunjukkan bahwa tidak terdapat perbedaan dalam mendeteksi spesies babi ternak dengan babi hutan $(p \geq 0.05)$, tetapi terdapat perbedaan pada sampel bentuk mentah dengan bakso $(p<0.05)$. Metode ELISA dan $q P C R$ dapat dijadikan sebagai metode pengujian untuk mengidentifikasi pencampuran spesies yang tidak dikehendaki, khususnya daging babi pada pangan asal hewan berbahan dasar daging sapi yang beredar di masyarakat.
\end{abstract}

Kata kunci: penambahan, daging babi ternak, daging babi hutan, ELISA, real-time PCR

\begin{abstract}
The aim of this research is to identify and analyse the presence of pork and wild boar meat in beef and beef product by using ELISA and real-time PCR (qPCR) methods. The samples consisted of 20 porks and 20 wild boar meats. They were divided into 5 concentrations such as $2 \%, 1 \%, 0.5 \%, 0.25 \%$, and $0.125 \%$ which were homogenized with either raw or cooked beef mixture. The research used sandwich ELISA and realtime PCR (qPCR) probe based with commercial kit. The primers and probes of qPCR were not informed because they were included in master mix commercial kit. The result of ELISA showed that raw meat samples and cooked samples that consisted of pork and wild boar meat were able to detect in concentration of $0.25 \%$. Meanwhile the result of real-time PCR showed that raw meat and cooked samples were able to detect in concentration of $0.125 \%$. There were no significant difference in optical density (OD) between pork and wild boar meat using ELISA ( $p \geq 0.05$ ), but there were significant difference between raw and cooked samples using ELISA $(p<0.05)$. There were no significant difference in cycle threshold $(C t)$ value between pork and wild boar meat using real-time PCR $(p \geq 0.05)$ but there were significant difference between raw and cooked samples using realtime PCR $(p<0.05)$. According to the result, ELISA and real-time PCR methods can be used to identify alduteration of pork and wild boar meat in beef and beef product.
\end{abstract}

Keywords: alduteration, ELISA, pork and wild boar meat, real-time PCR 


\section{PENDAHULUAN}

Peningkatan pendapatan penduduk di Indonesia mempengaruhi pola hidup masyarakat untuk mengonsumsi daging dan poduk olahannya dalam pemenuhan kebutuhan protein hewani. Penyelenggaraan kegiatan untuk melindungi kesehatan dan ketenteraman batin masyarakat merupakan aspek penting dari bidang Kesehatan Masyarakat Veteriner (Kesmavet) berdasarkan Peraturan Pemerintah RI nomor 95 tahun 2012 tentang Kesehatan Masyarakat Veteriner dan Kesejahteraan Hewan. Aktivitas kese-hatan masyarakat veteriner dilakukan melalui pen-jaminan higiene dan sanitasi pada rantai produksi produk hewan, penjaminan produk hewan dalam hal kehalalan bagi yang dipersyaratkan, keamanan, kesehatan dan keutuhan serta pengendalian dan penanggulangan zoonosis.

Pengawasan terhadap pangan asal hewan terkait dengan penambahan maupun pemalsuan daging babi sebagai daging sapi perlu dilakukan agar dapat mencegah adanya kemungkinan kerugian ekonomi akibat substitusi penipuan atau pemalsuan, men-cegah adanya bahaya kesehatan dan menyebabkan reaksi alergi tertentu (Bottero dan Dalmasso 2011) serta menjamin ketenteraman batin masyarakat terkait aspek halal terhadap pangan asal hewan yang beredar. Substitusi daging kuda pada produk olahan daging sapi di Eropa pada tahun 2013 menjadi perhatian di seluruh dunia karena adanya pemalsuan terhadap suatu produk makanan (Masiri et al., 2017).

Aspek halal sangat perlu diperhatikan dalam rangka melindungi konsumen terutama umat muslim dari pemalsuan berupa penambahan daging babi dalam produk makanan (Nakyinsige et al., 2012). Kejadian pemalsuan dan substitusi daging babi terhadap daging sapi dan produk olahannya di Indonesia sering terjadi ketika harga daging sapi melonjak tinggi akibat kelangkaan stok daging sapi menjelang hari raya keagamaan dan tahun baru. Babi ternak dan babi hutan yang tidak mendapatkan pengawasan oleh instansi yang membidangi fungsi kesehatan hewan dan kesehatan masyarakat veteriner juga memiliki risiko dalam penularan zoonosis dan foodborne disease. Risiko penularan zoonosis seperti cysticercosis dan trichinellosis dapat terjadi karena mengonsumsi daging babi hutan yang proses pemotongannya tidak melalui tahap pemeriksaan kesehatan, baik terhadap hewan hidup (antemortem) maupun daging dan jeroan yang dihasilkan (postmortem).

Salah satu upaya penjaminan pangan asal hewan dilakukan dengan cara pengembangan metode untuk mengidentifikasi spesies terkait dengan analisis kesehatan dan kehalalan suatu produk hewan. Beberapa metode uji yang digunakan saat ini antara lain enzyme-linked immunosorbent assay (ELISA) (Asensio et al., 2008; Kuswandi et al., 2017), electronic nose (enose), gas chromatography mass spectrometer with headspace analyzer (GCMS-HS) (Nurjuliana et al., 2011; Kuswandi et al., 2017), imunokromatografi atau yang dikenal sebagai rapid test (Kuswandi et al., 2017), polymerase chain reaction (PCR) (Pestana et al. 2010; Soares et al., 2013; Kim et al., 2016; Al-Kahtani et al., 2017; Perestam et al., 2017) dan DNA hybridization (Ballin et al., 2009) serta liquid chromatography-mass spectrometry (LC-MS) (Klein-nijenhuis et al., 2018).

Risiko pemalsuan daging babi sebagai daging sapi dan produk olahan daging sapi yang beredar perlu mendapat pengawasan untuk menjamin produk hewan yang aman, sehat, utuh dan halal serta berdaya saing. Penelitian ini bertujuan untuk mengidentifikasi dan menganalisis kandungan daging babi ternak dan babi hutan baik yang mentah (raw) maupun yang diolah (cooked) di dalam pangan asal hewan berbahan dasar daging sapi menggunakan metode uji ELISA dan real-time PCR.

\section{BAHAN DAN METODE}

\section{Disain Penelitian}

Rancangan penelitian yang digunakan adalah studi eksperimental, yaitu dengan melakukan percobaan di laboratorium terhadap kemampuan suatu metode uji untuk mendeteksi dan mengidentifikasi spesies pada daging. Jenis sampel yang digunakan adalah daging babi ternak, daging babi hutan, produk olahan bakso babi ternak, dan bakso babi hutan.

\section{Perlakuan Sampel}

Jenis sampel yang digunakan adalah daging babi ternak, daging babi hutan, produk olahan bakso babi ternak dan bakso babi hutan dalam campuran daging sapi. Sampel daging babi ternak dan babi hutan berasal dari 2 ekor babi ternak dan 2 ekor babi hutan yang kemudian dibagi menjadi 4 kelompok perlakuan yang terdiri dari daging babi ternak mentah (raw), olahan bakso daging babi ternak (cooked), daging babi hutan mentah (raw), dan olahan bakso daging babi hutan (cooked) sehingga besaran sampel yang digunakan adalah 40 sampel yang terdiri dari 20 daging babi ternak dan 20 daging babi hutan yang dibagi dalam 5 konsentrasi yang berbeda untuk setiap metode uji (Tabel 1). 
Tabel 1 Perlakuan dan besaran sampel

\begin{tabular}{lcccccc}
\hline \multicolumn{1}{c}{ Jenis Sampel } & \multicolumn{7}{c}{ Konsentrasi } & \multirow{2}{*}{ Jumlah } \\
\cline { 2 - 5 } & $2 \%$ & $1 \%$ & $0,5 \%$ & $0,25 \%$ & $0,0125 \%$ & 10 \\
Daging babi ternak (raw) & 2 & 2 & 2 & 2 & 2 & 10 \\
Olahan bakso babi ternak (cooked) & 2 & 2 & 2 & 2 & 2 & 10 \\
Daging babi hutan (raw) & 2 & 2 & 2 & 2 & 2 & 10 \\
Olahan bakso babi hutan (cooked) & 2 & 2 & 2 & 2 & 2 & 40 \\
Total & & & & & & \\
\hline
\end{tabular}

\section{Persiapan Sampel}

Persiapan sampel daging mentah dilakukan dengan menambahkan daging babi ternak dan babi hutan dengan konsentrasi masing-masing sebesar $2 \%, 1 \%, 0.5 \%, 0.25 \%$, dan $0.125 \%$ dalam daging sapi. Produk olahan daging yang digunakan pada penelitian ini adalah bakso daging sapi yang memiliki kandungan daging sapi sebesar $75 \%$. Sampel berupa produk olahan daging disiapkan dengan menambahkan daging babi ternak dan babi hutan dengan konsentrasi masing-masing sebesar $2 \%, 1 \%, 0.5 \%, 0.25 \%$, dan $0.125 \%$ dalam adonan bakso daging sapi yang terdiri dari daging sapi, tepung tapioka, garam dan lada. Setiap sampel disiapkan sebesar $250 \mathrm{~g}$ untuk masing-masing konsentrasi.

\section{Identifikasi Spesies Babi menggunakan Enzyme Linked Immunosorbent Assay (ELISA)}

Metode pengujian menggunakan Sandwhich ELISA sesuai prosedur standar pengujian kit komersial Porcine Detection Kits for Processed Meat (Biokits Neogen Corp, USA). Ekstraksi sampel dilakukan dengan menghomogenisasi $25 \mathrm{~g}$ sampel dengan $100 \mathrm{ml} \mathrm{NaCl}$ fisiologis, kemudian dipanaskan dengan cara direbus pada suhu $95-100{ }^{\circ} \mathrm{C}$ selama 15 menit lalu dibiarkan pada suhu ruang selama 15 menit. Setelah itu, sampel disaring dan disentrifus kemudian diambil $100 \mu$ l lapisan bawah untuk uji lanjut menggunakan ELISA. Setiap pengujian ELISA selalu disertai kontrol positif dan kontrol negatif. Setiap sampel yang diuji ELISA dilakukan ulangan sebanyak 2 kali. Pembacaan hasil dilakukan dengan ELISA Reader pada panjang gelombang $450 \mathrm{~nm}$ dengan melihat nilai Optical Density (OD). Penentuan hasil uji positif atau negatif dilakukan dengan membandingkan nilai OD dan nilai cut off. Nilai cut off diperoleh dengan rumus:

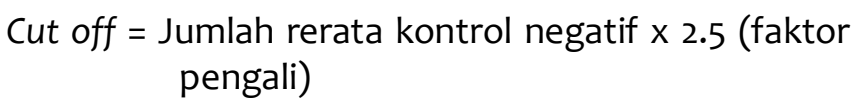

Jika nilai $O D \geq$ nilai cut off maka sampel dinyatakan positif. Jika nilai $O D \leq$ nilai cut off maka sampel dinyatakan negatif (Biokits Neogen Corp., USA).

\section{Identifikasi Spesies Babi Menggunakan Metode Real-time PCR ( $q P C R$ )}

Identifikasi penambahan daging babi pada daging sapi mentah dan olahan dengan metode PCR pada penelitian ini menggunakan teknik real-time PCR (qPCR). Uji qPCR menggunakan kit komersial berdasarkan probe. Sekuens primer dan probe tidak diinformasikan di dalam kit komersial karena primer dan probe sudah termasuk di dalam master mix spesifik spesies babi. Sampel daging dan bakso diekstraksi sesuai prosedur standar dari Dneasy Mericon Food Kit (Qiagen, Germany).

Ekstraksi DNA dilakukan pada setiap konsentrasi. DNA hasil ekstraksi langsung digunakan untuk proses amplifikasi PCR. Proses amplifikasi diawali dengan penambahan master mix PCR menggunakan Mericon Pig Kit (Qiagen, Germany) yang terdiri dari mericon assay dan multiplex PCR master mix. Setiap pengujian real-time $P C R$ selalu disertai kontrol positif dan kontrol negatif. Setiap sampel yang diuji dengan real-time PCR dilakukan ulangan sebanyak 2 kali. Sampel yang akan diidentifikasi memerlukan reconstituted mericon assay sebanyak $10 \mu \mathrm{l}$ ditambah dengan $10 \mu \mathrm{l}$ DNA total sampel hasil ekstraksi sehingga total reaksi sebanyak $20 \mu$ l. Amplifikasi DNA dilakukan pada thermal cycler Rotor-Gene Q (Qiagen, Germany). Program amplifikasi pada metode uji real-time PCR yaitu denaturasi awal (HOLD) $95{ }^{\circ} \mathrm{C}$ selama 5 menit, denaturasi $95{ }^{\circ} \mathrm{C}$ selama 15 detik, Annealing $60^{\circ} \mathrm{C}$ selama 23 detik dan extension $72{ }^{\circ} \mathrm{C}$ selama 10 detik, dengan siklus sebanyak 45 kali (Qiagen, Germany). Deteksi target menggunakan pewarna reporter FAM dengan channel Green (FAM) sedangkan deteksi internal control dengan pewarna reporter MAX dengan channel Yellow (VIC). Interpretasi hasil positif dinyatakan apabila sampel DNA menunjukan adanya amplifikasi pada detection system (FAM dan VIC) dengan nilai cycle 
threshold $(\mathrm{Ct})<35$, hasil dinyatakan negatif apabila sampel DNA tidak menunjukan adanya amplifikasi pada detection system. Jika nilai Ct antara 35-45, maka pengujian diulang. Sampel DNA dan internal amplification control yang tidak teramplifikasi kemungkinan karena sampel mengandung PCRinhibiting substances sehingga perlu dilakukan isolasi dan purifikasi sampel kembali.

\section{Analisis Data}

Analisis data penelitian pada metode ELISA dan real-time PCR dilakukan dengan uji t untuk melihat adanya perbedaan antara deteksi daging babi ternak dengan daging babi hutan baik dalam bentuk mentah (raw) maupun olahan (cooked) menggunakan metode ELISA dan real-time PCR (qPCR).

\section{HASIL PENELITIAN}

\section{Identifikasi Spesies Babi menggunakan ELISA}

Penelitian ini menggunakan babi ternak dan babi hutan pada campuran daging sapi dalam bentuk mentah (raw) dan olahan bakso. Metode ELISA sandwich pada penelitian ini mampu mendeteksi adanya kandungan daging babi ternak maupun babi hutan dalam pangan asal hewan hingga konsentrasi $0.25 \%$ (Tabel 2). Penentuan hasil yang terdeteksi spesies babi dianalisis berdasarkan nilai cut off. Nilai cut off pada konsentrasi $0.25 \%$ adalah 0.203 sehingga nilai absorbansi yang melebihi nilai cut off adalah positif.

\section{Identifikasi Spesies Babi menggunakan qPCR}

Hasil pengujian real-time PCR menunjukkan bahwa babi ternak dan babi hutan pada campuran daging sapi dalam bentuk mentah (raw meat) dan olahan bakso masih dapat terdeteksi hingga konsentrasi $0.125 \%$ (Tabel 3). Amplification plot cycle threshold $(\mathrm{Ct})$ metode real-time $\mathrm{PCR}$ identifikasi spesies babi pada konsentrasi $0.125 \%$ dapat dilihat pada Gambar 1.

\section{PEMBAHASAN}

Identifikasi Spesies Babi menggunakan ELISA

Hasil penelitian ini menunjukkan bahwa seluruh sampel daging babi ternak dan babi hutan baik mentah maupun olahan dapat terdeteksi hingga konsentrasi $0.25 \%$ pada campuran daging sapi menggunakan ELISA sandwich. Uji t terhadap nilai

Tabel 2 Nilai absorbansi uji ELISA identifikasi spesies babi konsentrasi 0,25\%

\begin{tabular}{|c|c|c|c|c|}
\hline \multirow{2}{*}{ Konsentrasi } & \multirow{2}{*}{ Sampel } & \multicolumn{2}{|c|}{ Absorbansi } & \multirow{2}{*}{ Hasil } \\
\hline & & 1 & 2 & \\
\hline \multirow{10}{*}{$0,25 \%$} & Daging babi ternak $A$ & 0,436 & 0,432 & + \\
\hline & Daging babi ternak B & 0,422 & 0,401 & + \\
\hline & Bakso babi ternak A & 0,296 & 0,268 & + \\
\hline & Bakso babi ternak B & 0,214 & 0,209 & + \\
\hline & Daging babi hutan A & 0,357 & 0,345 & + \\
\hline & Daging babi hutan B & 0,395 & 0,379 & + \\
\hline & Bakso babi hutan A & 0,275 & 0,271 & + \\
\hline & Bakso babi hutan B & 0,214 & 0,211 & + \\
\hline & Kontrol positif & 0,677 & * & + \\
\hline & Kontrol negatif & 0,094 & 0,069 & - \\
\hline
\end{tabular}

$+:$ terdeteksi

- : tidak terdeteksi

* : hanya menggunakan satu ulangan

Tabel 3 Uji t terhadap nilai optical density (OD) metode ELISA identifikasi spesies babi ternak dan babi hutan

\begin{tabular}{cccc}
\hline & Jenis sampel & Rataan absorbansi & P \\
\hline \multirow{2}{*}{ Mentah (raw) } & Daging babi ternak & 0,389 & 0,2087 \\
& Daging babi hutan & 0,355 & 0,2910 \\
& Bakso babi ternak & 0,298 & 0,257 \\
\hline
\end{tabular}




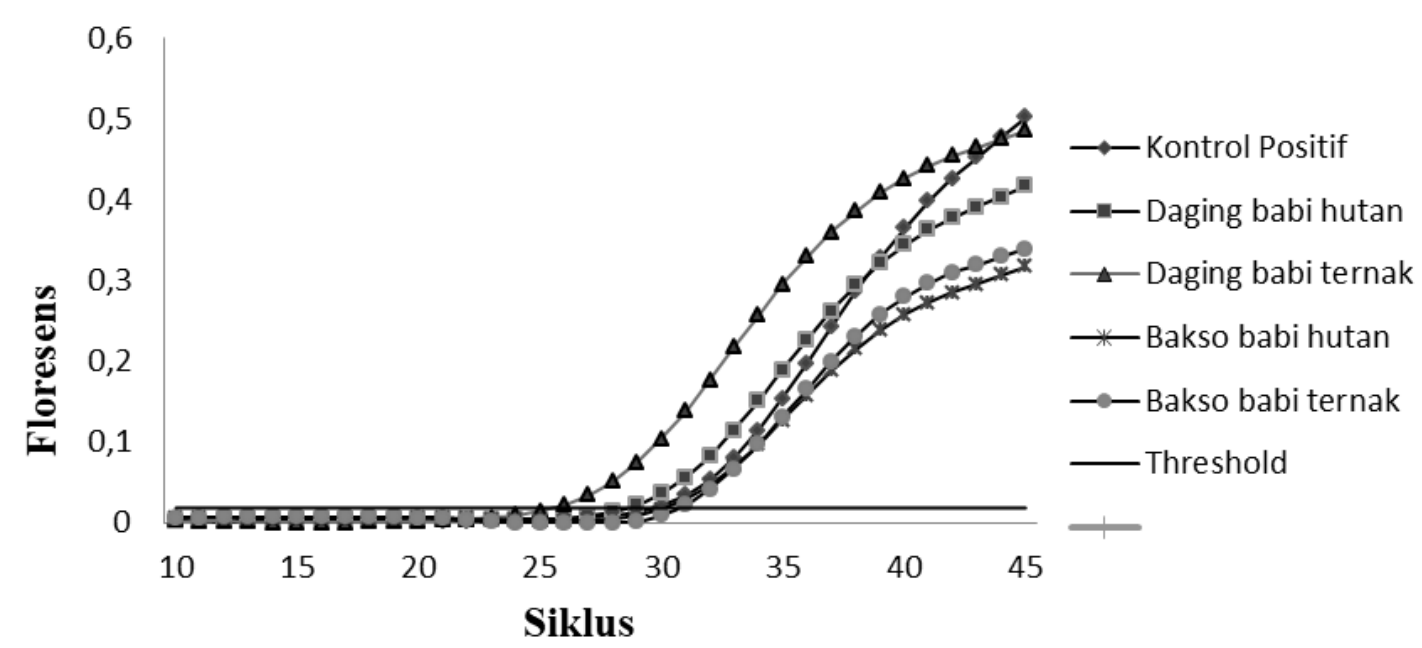

Gambar 1 Amplification plot cycle threshold (Ct) uji Real-time PCR identifikasi spesies babi pada konsentrasi 0,125\%

OD metode ELISA (Tabel 4) menunjukkan bahwa tidak terdapat perbedaan dalam mendeteksi spesies babi ternak dengan babi hutan ( $p \geq 0.05)$.

Rataan nilai OD produk daging babi mentah (raw) lebih tinggi dibandingkan dengan rerata nilai OD produk olahan bakso babi (cooked). Hal tersebut dapat terlihat pada uji $t$ (Tabel 5) yang menunjukkan bahwa terdapat perbedaan nyata antara deteksi daging babi ternak dan babi hutan dalam bentuk mentah (raw meat) dan olahan bakso (cooked) menggunakan metode ELISA $(p<0.05)$. Hal tersebut kemungkinan selama proses pemanasan dan pengolahan pada pembuatan produk olahan sehingga tidak terdeteksi oleh antibodi pada uji ELISA (Kim et al. 2017).

Metode ELISA yang paling umum digunakan dalam analisis komponen pangan adalah ELISA sandwich, dan ELISA tidak langsung (Asensio et al. 2008). ELISA sandwich dilakukan secara kualitatif yang mudah dan cepat dalam aplikasinya serta memiliki sensitivitas baik. Teknologi ELISA sandwich dan indirect memiliki thermal stable-soluble protein yang baik digunakan untuk mendeteksi daging babi mentah maupun olahan pada konsentrasi yang rendah (Kim et al. 2017; Asensio et al. 2008). ELISA indirect baik kompetitif maupun non kompetitif dilakukan secara kuantitatif dengan membuat serial dilution kontrol positif untuk mebentuk kurva standar yang digunakan sebagai penentuan hasil uji ELISA (Jiang et al. 2018). Penelitian yang dilakukan oleh Zvereva et al. (2015) menunjukkan bahwa ELISA sandwich 20 kali lebih sensitif dibandingkan dengan ELISA indirect kompetitif.

ELISA sandwich dapat digunakan sebagai uji skrining maupun uji konfirmasi di laboratorium untuk mendeteksi komponen tertentu dalam pangan asal hewan secara kualitatif dan waktu yang diperlukan singkat karena sampel tidak perlu dipurifikasi terlebih dahulu. Pengujian menggunakan metode ELISA pada penelitian ini membutuhkan waktu sekitar 3 jam, hampir sama dengan penelitian yang dilakukan oleh Perestam et al. (2017) yaitu selama 3.3 jam.

\section{Identifikasi Spesies Babi menggunakan qPCR}

Penelitian ini hanya menggunakan konsentrasi daging babi ternak dan babi hutan pada campuran daging sapi dalam bentuk mentah maupun olahan bakso hingga $0.125 \%$. Metode real-time PCR pada penelitian ini mampu mendeteksi adanya penambahan daging babi ternak maupun babi hutan dalam pangan asal hewan hingga konsentrasi $0.125 \%$ bahkan

Tabel 4 Uji t terhadap nilai optical density (OD) metode ELISA identifikasi spesies babi dalam bentuk mentah dan olahan bakso

\begin{tabular}{cccc}
\hline & Jenis sampel & Rataan absorbansi & P \\
\hline Babi ternak & Mentah & 0,389 & 0,0242 \\
\multirow{3}{*}{ Babi hutan } & Olahan bakso & 0,298 & \\
& Mentah & 0,355 & 0,0004 \\
& Olahan bakso & 0,257 & \\
\hline
\end{tabular}


Tabel 5 Nilai cycle threshold uji real-time PCR identifikasi spesies babi konsentrasi 0,125\%

\begin{tabular}{clccc}
\hline \multirow{2}{*}{ Konsentrasi } & \multicolumn{1}{c}{ Sampel } & \multicolumn{2}{c}{ Ct-Value } & Hasil \\
\cline { 3 - 4 } & Daging babi ternak A & 25,68 & 25,26 & + \\
& Daging babi ternak B & 27,32 & 27,61 & + \\
& Bakso babi ternak A & 31,32 & 32,31 & + \\
\multirow{2}{*}{$0,125 \%$} & Bakso babi ternak B & 31,48 & $30,79+$ & + \\
& Daging babi hutan A & 26,90 & 28,15 & + \\
& Daging babi hutan B & 28,72 & $28,08+$ & + \\
& Bakso babi hutan A & 29,29 & 30,23 & + \\
& Bakso babi hutan B & 30,23 & 30,47 & + \\
\hline
\end{tabular}

+: terdeteksi

Tabel 6 Uji t terhadap nilai cycle threshold $(\mathrm{Ct})$ metode $\mathrm{qPCR}$ identifikasi spesies babi ternak dan babi hutan

\begin{tabular}{llll}
\hline & Jenis sampel & Rataan Ct & P \\
\hline Mentah (raw) & Daging babi ternak & 25,113 & 0,1307 \\
& Daging babi hutan & 26,321 & 0,4286 \\
& Bakso babi ternak & 27,594 & 28,272 \\
\hline
\end{tabular}

kurang dari $0.125 \%$ apabila menggunakan konsentrasi yang lebih rendah. Penelitian deteksi adanya spesies babi menggunakan teknik qPCR pernah dilakukan oleh Al-Kahtani et al. (2017) dengan hasil teknik ini dapat mendeteksi hingga konsentrasi $1 \%$ di dalam campuran daging, daging babi dengan konsentrasi 10\% dalam campuran daging sapi oleh Perestam et al. (2017) dan konsentrasi $0.001 \%$ oleh Lubis et al. (2017).

Uji t terhadap nilai Ct (Tabel 6) pada babi ternak dan babi hutan yang diperoleh pada penelitian ini menunjukkan bahwa tidak terdapat perbedaan dalam mendeteksi spesies babi ternak dengan babi hutan menggunakan metode realtime PCR ( $p \geq 0.05)$. Hal ini sejalan dengan penelitian yang dilakukan oleh Fajardo et al. (2008) yaitu penggunaan metode polymerase chain reaction-restriction fragment length polymorphism (PCR-RFLP) untuk membedakan antara spesies babi ternak dengan babi hutan pada produk pangan.

Uji t terhadap nilai Ct (Tabel 7) menunjukkan bahwa terdapat perbedaan antara deteksi daging babi ternak dan babi hutan dalam bentuk mentah (raw) dengan olahan bakso (cooked) menggunakan metode real-time PCR $(p<0.05)$. Hal ini terlihat pada nilai $\mathrm{Ct}$ produk bakso berkisar antara siklus 29-32 lebih tinggi dibandingkan dengan produk mentah yaitu pada siklus 25-28.

Nilai Ct yang tinggi dapat disebabkan karena konsentrasi DNA yang terlalu tinggi maupun terlalu rendah (Pestana et al. 2010). Pengukuran konsentrasi DNA terhadap produk daging baik dalam ben- tuk mentah maupun olahan bakso pada penelitian ini tidak dilakukan. Nilai $\mathrm{Ct}$ yang tinggi pada penelitian ini kemungkinan terjadi karena jumlah konsentrasi DNA yang terdeteksi pada bakso lebih rendah dibandingkan produk daging mentah. Hal ini terjadi karena produk pangan seperti bakso mengalami proses pengolahan melalui pemanasan dengan perebusan sampai mendidih sehingga jumlah DNA pada matriks lebih sedikit dan terjadi degradasi (Cankar et al. 2006). Degradasi DNA dapat terjadi akibat pemanasan tinggi menggunakan panas kering (oven) pada suhu $130{ }^{\circ} \mathrm{C}-190{ }^{\circ} \mathrm{C}$ dan menggunakan air panas (pressure system) pada suhu $100^{\circ} \mathrm{C}-110^{\circ} \mathrm{C}$ (Karni et al. 2013). Degradasi DNA dapat mempengaruhi hasil uji realtime PCR yaitu terlihat pada dengan cycle threshold yang tinggi (Ballin et al. 2009). Meskipun terdapat perbedaan, nilai cycle threshold pada penelitian ini masih berada pada batas kriteria yang dipersyaratkan oleh kit komersial yang digunakan $(\mathrm{Ct}<35)$.

\section{Kemampuan Uji Identifikasi Spesies Babi}

Metode ELISA dan real-time PCR untuk mengidentifikasi spesies babi pada campuran daging sapi dalam bentuk mentah maupun olahan bakso, menggunakan babi ternak dan babi hutan dengan hasil deteksi pada konsentrasi terendah yang berbeda. Hasil pengujian ELISA menunjukkan bahwa seluruh sampel masih dapat terdeteksi pada konsentrasi $0.25 \%$, sedangkan hasil pengujian realtime PCR menunjukkan bahwa seluruh sampel masih dapat terdeteksi pada konsentrasi 0.125\% (Tabel 8). 
Tabel 7 Uji t terhadap nilai cycle threshold (Ct) metode qPCR identifikasi spesies babi dalam bentuk mentah dan olahan bakso

\begin{tabular}{llll}
\hline Jenis sampel & & Rataan Ct & $\mathrm{P}$ \\
\hline Babi ternak & Mentah & 25,113 & 0,0059 \\
& Olahan bakso & 27,594 & \\
Babi hutan & Mentah & 26,321 & 0,0166 \\
& Olahan bakso & 28,272 & \\
\hline
\end{tabular}

Tabel 8 Konsentrasi terendah berdasarkan hasil uji metode uji cepat, ELISA dan real-time PCR identifikasi spesies babi pada pangan berbahan dasar daging sapi

\begin{tabular}{ccc}
\hline Sampel & \multicolumn{2}{c}{ Konsentrasi } \\
\cline { 2 - 3 } & ELISA & qPCR \\
\hline Daging babi ternak & $0,25 \%$ & $0,125 \%$ \\
Daging babi hutan & $0,25 \%$ & $0,125 \%$ \\
Bakso babi ternak & $0,25 \%$ & $0,125 \%$ \\
Bakso babi hutan & $0,25 \%$ & $0,125 \%$ \\
\hline
\end{tabular}

Metode ELISA baik digunakan sebagai uji rutin karena dapat digunakan untuk sampel dalam jumlah besar, waktu yang relatif cepat, peralatan yang cukup canggih namun dengan harga yang terjangkau (Asensio et al. 2008). ELISA memiliki stabilitas yang baik terhadap antigenik epitop pada perlakuan pemanasan dan adanya penambahan sodium nitrate, sodium chloride, phosphates, citrates, dan ascorbates (Zvereva et al. 2015). Konfirmasi dengan uji laboratorium untuk identifikasi spesies yang lebih akurat baik berbasis protein maupun analisis DNA mutlak diperlukan untuk menghindari hasil negatif palsu maupun positif palsu.

Metode real-time PCR merupakan analisis berdasarkan DNA atau genetik yang jauh lebih stabil terhadap pemanasan dibandingkan uji berbasis protein (ELISA) sehingga mampu mendeteksi daging babi dan babi hutan baik dalam bentuk mentah (raw) maupun olahan (Lockley dan Bardsley 2000). Analisis uji berdasarkan deteksi genetika lebih sensitif dan spesifik, tetapi membutuhkan keterampilan, waktu dan peralatan laboratorium yang canggih sehingga biaya yang dikeluarkan cukup tinggi. Penelitian ini hanya menggunakan konsentrasi daging babi dalam campuran daging sapi paling rendah sebesar $0.125 \%$. Penambahan daging babi pada pangan berbahan dasar daging sapi pada konsentrasi kurang dari $0.125 \%$ kemungkinan masih dapat terdeteksi oleh metode real-time PCR.

Hasil penelitian menunjukkan bahwa penggunaan kit komersial pada metode ELISA dan realtime PCR dapat mendeteksi daging babi hutan selain daging babi ternak pada pangan asal hewan berbahan dasar daging sapi pada konsentrasi yang sangat rendah. Konsentrasi kandungan spesies babi yang sangat rendah pada produk makanan sangat jarang terjadi untuk tujuan pemalsuan karena tidak menguntungkan secara ekonomi (Al-Kahtani et al. 2017). Penambahan daging babi terutama daging babi hutan pada produk pangan berbahan dasar daging sapi di lapangan pada umumnya dilakukan sebanyak lebih dari 50\%, kecuali pada produk pangan yang menggunakan komponen dari spesies lain sebagai bahan tambahan untuk pengental atau penstabil makanan yang hanya menggunakan konsentrasi sangat rendah. Hal tersebut dilakukan .untuk memperoleh keuntungan setinggi-tingginya, sehingga metode ELISA dan real-time PCR dapat digunakan untuk mendeteksi spesies pada produk pangan asal hewan karena mampu mendeteksi pada konsentrasi kurang dari $2 \%$.

Metode enzyme linked immunosorbent assay (ELISA) dan real-time PCR memiliki kemampuan yang baik dalam mengidentifikasi spesies babi pada pangan asal hewan. Tingkat kemampuan uji berdasarkan kemampuan mendeteksi daging babi ternak dan babi hutan dalam daging sapi, baik dalam bentuk mentah maupun olahan secara berurutan dari yang paling tinggi ke yang paling rendah adalah realtime PCR dan ELISA. Metode ELISA dan real-time PCR dapat dijadikan sebagai metode pengujian untuk mengidentifikasi spesies yang tidak dikehen-daki pada pangan asal hewan yang beredar di masyarakat, khususnya terhadap penambahaan daging babi pada pangan asal hewan berbahan dasar daging sapi. 


\section{UCAPAN TERIMA KASIH}

Kami mengucapkan terima kasih kepada Badan Sumber Daya Manusia Kementerian Pertanian yang telah memberikan beasiswa dan dana penelitian. Kami juga mengucapkan terimakasih kepada Kepala Balai Pengujian Mutu dan Sertifikasi Produk Hewan Bogor beserta staf dan jajarannya atas bantuan dan fasilitas laboratorium dalam pelaksanaan penelitian ini.

"Penulis menyatakan tidak ada konflik kepentingan dengan pihak-pihak yang terkait dalam penelitian ini"

\section{DAFTAR PUSTAKA}

Al-Kahtani HA, Ismail EA, Ahmed MA. 2017. Pork detection in binary meat mixtures and some commercial food products using conventional and real-time PCR techniques. Food chemistry 219: 54-60.

Asensio L, Gonzalez I, Garcia T, Martin R. 2008. Review Determination of food authenticity $b$ linked immunosorbent assay (ELISA). Food Control 19: 1-8.

Ballin NZ, Vogensen FK, Karlsson AH. 2009. Species determination - Can we detect and quantify meat adulteration?. Meat Science 83: 165-174.

Bottero MT, Dalmasso A. 2011. Review Animal species identification in food products: evolution of biomolecular methods. The Veterinary Journal 190: 34-38.

Cankar K, Stebih D, Dreo T, Zel J, Gruden K. 2006. Critical points of DNA quantification by real-time PCR-effects of DNA extraction method and sample matrix on quantification of genetically modified organisms. BMC Biotechnology 6:37.

Chen FC, Hsieh YHP. 2000. Detection of pork in heatprocessed meat products by monoclonal antibody-based ELISA. Journal AOAC International 83: 79-85.

Fajardo V, Gonza'lez I, Martin I, Rojas M, Hernandez PE, Garcia T, Martin E. 2008. Differentiation of European wild boar (Sus scrofa scrofa) and domestic swine (Sus scrofa domestica) meats by PCR analysis targeting the mitochondrial D-loop and the nuclear melanocortin receptor 1 (MC1R) genes. Meat Science 78: 314-322.

Jiang X, Fuller D, Hsieh YHP, Rao Q. 2018. Monoclonal antibody-based ELISA for the quantification of porcine hemoglobin in meat products. Food Chemistry 250:170-179.

Karni M, Zidon D, Polak P, Zalevsky Z, Shefi O. 2013. Thermal degradation of DNA. DNA and Cell Biology 32(6):1-4.

Kim JS, Kwon IJ, Kim MG, Chang JY, Shim WB. 2017. Production and preliminary characterization of Monoclonal antibodis highly specific to pork fat protein. Food Control 79:80-86.

Kim M, Yoo I, Lee SY, Hong Y, Kim HY. 2016. Quantitative detection of pork in commercial meat products by TaqMan real-time PCR assay targeting the mitochondrial D-loop region. Food Chemistry 210: 102-106.

Kleinnijenhuis AJ, Van Holthoon FL, Herregods G. 2018. Validation and theoritical justification of an LC-MS method for the animal species specific detection of gelatin. Food Chemistry 243:461467.

Kuswandi B, Gani AA, Ahmad M. 2017. Immuno strip test for detection of pork adulteration in cooked meatballs. Food Bioscience 19: 1-6.

Liu LH, Chen FC, Dorsey JL, Hsieh YHP. 2006. Sensitive monoclonal antibody-based sandwich ELISA for the detection of porcine skeletal muscle in meat and feed products. Food Science 71: M1-M6.

Lockley AK, Bardsley RG. 2000. DNA-based methods for food authentication. Trends in Food Science \& Technology 11(2): 67-77.

Lubis H, Salihah NT, Hossain MM, Ahmed MU. 2017. Development of fast and sensitive real-time qPCR assay based on a novel probe for detection of porcine DNA in food sample. Food Science and Technology 84: 686-692.

Masiri J, Benoit L, Thienes C, Kainrath C, BarriosLopez B, Agapov A, Dobritsa A, Nadala C, Sung SL, Samadpour M. 2017. A rapid, semiquantitative test for detection of raw and cooked horse meat residues. Food Control 76: 102-107.

Nakyinsige K, Che Man Y, Sazili AQ. 2012. Halal authenticity issues in meat and meat products. Meat Science 91: 207-214.

Nurjuliana M, Che Man YB, Mat Hashim D, Mohamed AKS. 2011. Rapid identification of pork for halal authentication using the electronic nose and gas chromatography mass spectrometer with headspace analyzer. Meat Science 88: 638-644.

Perestam AT, Fujisaki KK, Nava O, Hellberg RS. 2017. Comparison of real-time PCR and ELISA-based methods for the detection of beef and pork in processed meat products. Food Control 71: 346352. 
Pestana EA, Belak S, Diallo A, Crowther JR, Viljoen GJ. 2010. Early Rapid and Sensitive Veterinary Molecular Diagnostics Real-time PCR Application. Dordrecht (DE): Springer Science \& Bussiness Media.

Soares S, Amaral JS, Oliveira MBPP, Mafra I. 2013. A SYBR Green real-time PCR assay to detect and quantify pork meat in processed poultry meat products. Meat Science 94: 115-120.
Zvereva EA, Kovalev LI, Ivanov AV, Kovalena MA. Zherdev AV, Sishkin SS, Lissitsyn AB, Chernukha IM, Dzantiev BB. 2015. Enzyme immunoassay and proteomic charachterization of troponin I as a marker of mammalian muscle compounds in raw meat and some meat products. Meat Science. 105:46-52. 